\title{
Genetic characterization of Liriodendron seed orchards with EST-SSR markers
}

\author{
Xinfu Zhang ${ }^{1}$, Alanna Carlson', Zhenkun Tian², Margaret Staton ${ }^{3}$, Scott E. Schlarbaum ${ }^{4}$, John E. Carlson ${ }^{5}$ and Haiying Liang $^{1 *}$ \\ *Correspondence: hliang@clemson.edu

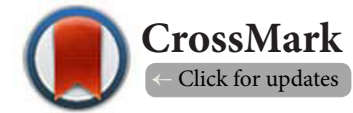 \\ 'Department of Genetics and Biochemistry, Clemson University, Clemson SC 29634, USA. \\ ${ }^{2}$ Beijing Forestry University, Beijing, China. \\ ${ }^{3}$ Department of Entomology and Plant Pathology, The University of Tennessee, Knoxville, TN 37996-4563, USA. \\ ${ }^{4}$ Department of Forestry, Wildlife \& Fisheries, The University of Tennessee, Knoxville, TN 37996-4563, USA. \\ ${ }^{5}$ Department of Ecosystem Science and Management and The Department of Plant Science, Pennsylvania State University, \\ University Park, PA 16802, USA.
}

\begin{abstract}
Liriodendron tulipifera L., is a wide-spread, fast-growing pioneering tree species native to eastern North America. Commonly known as yellow-poplar, tulip tree, or tulip-poplar, the species is valued, both ecologically and economically. It is perhaps the most commonly used utility hardwood in the USA, and is planted widely for reforestation and, in varietal forms, as an ornamental. Although most seedlings used for reforestation today derive from collections in natural populations, two known seed orchards, established from plus-tree selections, i.e. superior phenotypes, in the 1960's and 1970's have been used for local and regional planting needs in Tennessee and South Carolina. However, very little is known about the population genetics of yellow-poplar nor the genetic composition of the existing seed orchards. In this study, 194 grafted yellow-poplar trees from a Clemson, SC orchard and a Knoxville, TN orchard were genetically characterized with 15 simple sequence repeat (SSR) markers developed from expressed sequence tags (ESTs). Of the 15 EST-SSR markers, 14 had a polymorphic information content (PIC) of at least 0.5. There was no significant difference between the Clemson and Knoxville orchards in average effective number of alleles (5.93 vs 3.95), observed and expected heterozygosity (Ho: 0.64 vs 0.58; He: O.74 vs 0.70 ), Nei's expected heterozygosity (0.74 vs 0.58), or Shannon's Information index (1.84 vs 1.51). The larger Clemson orchard exhibited a significantly greater number of observed alleles than the Knoxville orchard (15.3 vs7.4). Overall, substantial genetic diversity is captured in the Clemson and Knoxville orchards.
\end{abstract}

Keywords: Genetic diversity, seed orchard, SSR markers, species

\section{Introduction}

Liriodendron tulipifera L., commonly known as yellow-poplar or tulip-poplar, is a wide-spread, fast-growing pioneering hardwood species of considerable economic value in the forests of eastern North America. Yellow-poplar is distributed predominantly east of the Mississippi River from the gulf coast to southern Canada ( $28^{\circ}$ to $43^{\circ}$ north latitude) [35]. According to the forest inventory analysis [11], as surveyed from 20062012 , the total saw log volume of $L$. tulipifera on timberland in the United States was 25.9 billion cubic feet, with the majority $(65 \%)$ located in the southeastern United States. The species is shade intolerant and highly competitive, growing faster than
Acer rubrum L. (red maple) and Quercus rubra L. (northern red oak) seedlings under a variety of silvicultural understory treatments (Beckage and Clark 2003). Yellow-poplar is often seen as a pioneering species in old fields. As a component of 16 forest cover types, this species' degree of dominance has created differentiation between the ecological communities [46]. In addition, yellow-poplar is valued as a nectar source for honey production, as a source of wildlife food (mast), and as a large shade tree in urban plantings [3]. The wood of yellow-poplar is used in a diverse range of products, such as in furniture, pallets and framing construction as well as pulp $[12,41])$. Chemical extracts from yellow-poplar wood or leaves have proven useful, 
Zhang et al. Journal of Plant Science \& Molecular Breeding 2015,

http://www.hoajonline.com/journals/pdf/2050-2389-4-1.pdf

doi: $10.7243 / 2050-2389-4-1$

such as sesquiterpenes which have an anti-tumor effect and antifeeding for herbivores [27], and antimicrobial alkaloids [2].

L. tulipifera has been cultivated since 1663 [5] and is currently widely planted in eastern forests. Although seed orchards have been established to meet local or regional planting needs in the U.S.A. [6,36], genetic diversity of Liriodendron seed orchards in relation to natural stands has not been studied. Because seed orchards is the bridge between breeding and silvicultural activities, genetic diversity of tree seeds orchards determines the genetic quality of future forest stands and forms the basis for further improving the management of genetic resources and for the genetic modification of cultivars to meet new environmental challenges. Thus, the lacking information limits utilization of these Liriodendron orchards in a tree improvement program.

The primary goal of our study was to determine the genetic composition and diversity in two Liriodendron seed orchards in the southeastern USA. The orchard residing in Knoxville, Tennessee, was established in 1966 and contains 100 grafted ramets, representing 31 genotypes or clones. The Clemson orchard in South Carolina was established in 1976 by grafting multiple ramets of 150 plus trees selected from throughout the 17,500-acre Clemson Experimental Forest by Dr. Roland E. Schoenike (http://www.clemson.edu/trails/history/schoenike. html\#top). Seeds from this orchard have been used for reforestation efforts for a number of years. Currently there are 165 surviving trees in the Clemson orchard. Besides $L$. tulipifera, the only other Liriodendron species is Liriodendron chinense, which is native to China and Vietnam.

Although the two species separated 10 16 million years ago [32], they are quite similar morphologically and are cross fertile [26,34], and the hybrids exhibit heterosis [31,39]. Because the incomplete records suggest that the Clemson orchard may contain L. chinense or hybrids, we first used the sequence of a chloroplast gene, maturase $K$ (matK), to discriminate the two Liriodendron species and their hybrids. Then we investigated the genetic diversity and allele richness among selections of this unique native species in each orchard as a first step toward contrasting orchard-produced seedling diversity with natural diversity. We chose simple sequence repeat (SSR) markers (also called microsatellites) in the study, because SSR markers are co-dominant, easily reproduced and scored, highly polymorphic, abundant through the genome, and have higher information content than isoenzyme and dominant markers [45].

\section{Materials and methods Plant materials and DNA isolation}

Fresh leaves of all Liriodendron trees (165) from the Clemson seed orchard and 31 trees from the Knoxville seed orchard were collected in the spring of 2013 and stored in plastic bags at $-80^{\circ} \mathrm{C}$ prior to DNA isolation. All these trees represented different clones as validated by the SSR markers used in this study. Leaves from a Liriodendron tulipifera tree (accession number $70921 \mathrm{H}$ ) from the US National Arboretum (collected by Kevin Conrad) were also included in the study. Total genomic DNA was isolated from leaves using a CTAB protocol as described in [16] and suspended in TE buffer (Tris base $6.1 \mathrm{~g} / \mathrm{L}, \mathrm{EDTA} 0.37 \mathrm{~g} / \mathrm{L}, \mathrm{pH}$ 8). The quality and concentrations of genomic DNA from individual plants were determined with a NanoDrop 3300 (Thermo Scientific, Wilmington, Delaware, USA) and by electrophoresis on $0.8 \%$ agarose gels.

\section{Distinguishing between two Liriodendron species based on maturase $\mathrm{K}$ sequence}

The record of the 165 surviving Liriodendron trees in the Clemson orchard is not complete. Therefore, the sequence of a chloroplast gene, maturase $K$ (matK) was used to discriminate between the species/hybrids. The matK sequence was amplified with forward (5'-CGATCTATTCATTCAATATTTC- $\left.3^{\prime}\right)$ and reverse primers ( $5^{\prime}$-TCTAGCACACGAAAGTCGAAGT- $3^{\prime}$ ) in a $12.5-\mu \mathrm{l}$ reaction containing $6.875 \mathrm{uL} \mathrm{ddH2O}, 1 \mathrm{uL} \mathrm{MgCl} 2(25 \mathrm{mM})$, $0.5 \mathrm{uL}$ forward primer (10uM), $0.5 \mathrm{uL}$ reverse primer (10uM), $0.25 \mathrm{uL}$ dNTPs (10 mM each), $0.25 \mathrm{uL} \mathrm{BSA}(0.8 \mathrm{ug} / \mathrm{uL}), 0.125$ uL Taq Pololymerase (5u/uL), $0.5 \mathrm{uL}$ DNA ( 20ng/ul), $2.50 \mathrm{uL}$ 5X PCR buffer (-Mg).

The conditions for polymerase chain reactions (PCR) were as follows: 5 minutes of initial denaturation at $94^{\circ} \mathrm{C}, 35$ cycles of touch-down PCR with 30 seconds of denaturation at $94^{\circ} \mathrm{C}$, 30 seconds of annealing at $60-50^{\circ} \mathrm{C}$ (first cycle $60^{\circ}$, then each subsequent cycle $1^{\circ} \mathrm{C}$ lower than the previous until $51^{\circ} \mathrm{C}$ annealing temperature, followed by 25 cycles each with a $50^{\circ} \mathrm{C}$ annealing temperature), and 3 minutes of extension at $72^{\circ} \mathrm{C}$, and a final extension at $72^{\circ} \mathrm{C}$ for 10 minutes. Before being sequenced with $1 \mathrm{ul}$ of $10 \mathrm{uM}$ forward or reverse primer, PCR products were cleaned with ExoAP mix (89 uL $\mathrm{H} 2 \mathrm{O}+10 \mathrm{uL} 5000 \mathrm{U} / \mathrm{mL}$ Antarctic Phosphatase +1 uL 20000U/ $\mathrm{mL}$ Exonuclease I) for 30 minutes in a reaction containing 1 $\mathrm{uL}$ of PCR product and $1 \mathrm{uL}$ of ExoAP mix, followed by a heat inactivation step at $80^{\circ} \mathrm{C}$ for $15 \mathrm{~min}$. An $834 \mathrm{bp}$-segment of maturase $\mathrm{K}$ gene from each tree was used for alignment with MUSCLE and curated with Gblocks, and a phylogenetic tree was built with maximum likelihood (PhyML) (http://www. phylogeny.fr/) [7].

The maturase $K$ gene sequence of L. tulipifera (Gl: 5731451), L. chinense (Gl: 7239759$)$, and a hybrid (Gl: 389955358 ) available in GenBank were included in the analysis.

\section{L. tulipifera EST-SSR markers, PCR amplification, and allele sizing}

Twenty simple sequence repeat (SSR) markers (also called microsatellites) were used to investigate the genetic composition of the Liriodendron seed orchards. These markers included seven Expressed Sequenced Tags (EST)SSR markers (LT002, LT015, LT021, LT086, LT096, LT131, LT157) previously characterized by electrophoresis on $8 \%$ polyacrylamide gels [42] and thirteen new markers (LTCU19, LTCU40, LTCU51, LTCU53, LTCU125, LTCU139, LTCU142, LTCU143, 
LTCU145, LTCU150, LTCU151, LTCU152, LTCU154) mined from a comprehensive EST dataset [22]. PCR amplification for each marker was performed with genomic DNA of Liriodendron trees from the Clemson and Knoxville seed orchards and the US National Arboretum. For a more cost-effective 153 primer screening, a M13 tail (5'-CACGACGTTGTAAAACGAC-3') was added to the $5^{\prime}$-end of the forward primer of each marker pair in order to amplify the fragments using a complementary adapter with a fluorescent dye (6-FAM, VIC, NED, or PET) at its 5'-end (Applied Biosystems, Foster City, California, USA). Polymerase chain reactions were carried out in a $12.5-\mu \mathrm{l}$ solution comprising: approximate $75 \mathrm{ng}$ DNA template, $0.052 \mathrm{U} / \mu \mathrm{L}$ Promega Taq DNA polymerase, $0.16 \mathrm{nM}$ forward primer, $0.4 \mathrm{nM}$ reverse primer, $0.4 \mathrm{nM}$ fluorescent M13 primer, $0.24 \mathrm{mM}$ each dNTPs, and $1.2 \times$ Promega PCR buffer. The PCR profile consisted of an initial denaturation at $94^{\circ} \mathrm{C}$ for 3 minutes followed by 10 cycles of 1 minute at $94^{\circ} \mathrm{C}, 1$ minute at annealing temperature (Table 1), and 1 minute 15 seconds at $72^{\circ} \mathrm{C}$, and then 35 cycles of 1 minute at $94^{\circ} \mathrm{C}, 1$ minute at $58^{\circ} \mathrm{C}$, and 1 minute at $72^{\circ} \mathrm{C}$, with a final extension of amplified DNA at $72^{\circ} \mathrm{C}$ for 5 minutes.

An aliquot of $1.5 \mu \mathrm{l}$ PCR products were treated with $1.5 \mu \mathrm{l}$ of 10-fold diluted ExoSAP-IT (Affymetrix Inc. Cleveland, $\mathrm{OH}$ USA) to remove single stranded primers which might influence fragment analysis at $37^{\circ} \mathrm{C}$ for 30 minutes and then at $80^{\circ} \mathrm{C}$ for 15 minutes. After being diluted to $100 \mathrm{ng} / \mu \mathrm{l}, 1 \mu \mathrm{l}$ of each sample was mixed with $0.1 \mu \mathrm{l}$ of LIZ600 and $8.9 \mu \mathrm{l}$ of $\mathrm{Hi}-\mathrm{Di}$ Formamide, denatured at $95^{\circ} \mathrm{C}$ for 5 minutes, and then put on ice for 10 minutes before being separated on an $A B I 3730$ Genetic Analyzer. The Dye set was DS-33 (6-FAM, VIC, NED, PET and LIZ). Allele sizes were scored with GeneMapper (4.0) (Applied Biosystems, Foster City, California, USA). Functional annotation of EST-SSRs was performed by applying a homology search of reassembled ESTs against the non-redundant (nr) NCBI database using the BLASTx algorithm [1].

\section{Data analysis}

MICRO-CHECKER [38] was employed to check for potential genotyping errors arising from large allele drop-out and stuttering. Observed and expected heterozygosities and polymorphic information content (PIC) were calculated using Cervus 2.0 [25]. Deviations from Hardy-Weinberg equilibrium and the Shannon's Information index were calculated with GENEPOP (http://genepop.curtin.edu.au/, Raymond and Rousset 1995).

\section{Results and discussion \\ Distinguishing between two Liriodendron species with maturase $K$ (matK) sequence}

It is not clear when L. chinense was first introduced to U.S.A., but the two Liriodendron species hybridize readily [26] and efforts in crossing have been well-documented [e.g., 31,34]. The two species are similar morphologically, except that $L$. chinense is smaller in stature and has larger, more deeply lobed leaves and smaller flowers. However, our attempt to tell these two species apart by morphology failed: the leaf shape varied depending on age (Supplementary figure S1) and the flowers were located at a too high for sampling. Molecular techniques including biochemical analysis [34], isozymes [14], and fingerprinting with random amplified polymorphic DNA (RAPD) [21] have been explored in discrimination of Liriodendron species and their hybrids. In 2012, Zhang et al., reported an SSR marker that amplified a 190-bp fragment from $L$. chinense, a 180 -bp fragment from $L$. tulipifera, and both 190- and 180-bp fragments from hybrid. In this study, matK sequence was employed. The matK gene locates within the intron of the trnK and codes for maturase like protein involved in Group II intron splicing [37]. The trnKUUU-matK region, ranging from approximately $2.2 \mathrm{~kb}$ (liverworts) to $2.6 \mathrm{~kb}$ (seed plants) in size, is universally present in land plants and only few exceptions of a secondary loss or reorganizations are known to date [40]. Because the matK gene evolves more rapidly, compared to other plastid genes, it has become a valuable marker for lower-level phylogenetic reconstruction of systematic and evolutionary studies. The Clemson seed orchard contains 165 surviving trees. The matK sequence was amplified from each of the 165 trees in the Clemson orchard (Supplementary figure S2). When the amplicons were pair-end sequenced, an 834-bp segment of high quality was obtained for each tree, representing 55\% of the full-length gene. There were only eight nucleotides different between the two Liriodendron species within the 834bp segment. As shown in Figure 1 and Supplementary figure S3, only Tree\#CU24 and \#134 were not L. tulipifera. Their hybrid status was established by having seven nucleotides different from $L$. tulipifera and 2 nucleotides different from $L$. Chinense. These results confirm the record of hybrids being planted in the Clemson Orchard. Thus, these two hybrids were excluded in the genetic composition analysis. Further, our study indicates that L. tulipifera, L. Chinense, and their hybrids contain unique nucleotide compositions in matK sequence that can be utilized in distinguishing the species and hybrids.

\section{Amplification of EST-SSR loci in Liriodendron}

No evidence for large allele dropout was found for any of the 20 markers. Stuttering occurred in five markers: LT131, LT157, LTCU40, LTCU142, and LTCU143, and these five markers were excluded in further analyses. All of the remaining 15 markers were polymorphic in both Clemson and Knoxville orchards. The 20 markers were also tested on one L. tulipifera and one L. chinense tree from the US National Arboretum. Eleven loci were heterozygous and one locus failed in the L. tulipifera tree. PCR amplification for all 20 markers was successful in the $L$. Chinense tree, although sizing in an ABI 3730 Genetic Analyzer failed for LT157 and LTCU142, due to stuttering. Fourteen loci were heterozygous in the L. chinense tree. This indicates a high frequency of transferability of L. tulipifera EST-SSR markers in L. Chinense, supporting the previous 
Table 1. Characteristics of 20 EST-SSR loci.

\begin{tabular}{|c|c|c|c|c|c|c|}
\hline $\begin{array}{l}\text { Marker } \\
\text { name }\end{array}$ & Repeat motif & $\begin{array}{l}\text { Forward primer } \\
\text { sequence }\left(5^{\prime}-3^{\prime}\right)\end{array}$ & $\begin{array}{l}\text { Reverse primer } \\
\text { sequence (5'-3') }\end{array}$ & $\begin{array}{l}\text { Expected size } \\
\text { (bp) }\end{array}$ & Stutering ${ }^{\mathrm{a}}$ & $\begin{array}{l}\text { Annealing } \\
\text { temperature }{ }^{0} \mathrm{C}\end{array}$ \\
\hline \multirow[t]{2}{*}{ LT002 } & $(\mathrm{GCA}) 8$ & CCTACCACCAGCA & TCTCGTCGCTGAAGAT & 189 & $\mathrm{~N}$ & 59 \\
\hline & & ATACCTA & ATG & & & \\
\hline \multirow[t]{2}{*}{ LT015 } & $(\mathrm{CCGAAC}) 5$ & TCCGTTATCTCTCT & CTAGACAGGTGCTCGG & 110 & $\mathrm{~N}$ & 59 \\
\hline & & CCAAAA & ATAC & & & \\
\hline \multirow[t]{2}{*}{ LT021 } & (TTC)8 & CAAATACCATTGC & ACGCATCCTCTTCCAC & 180 & $\mathrm{~N}$ & 57 \\
\hline & & ACCTTGT & TAC & & & \\
\hline \multirow[t]{2}{*}{ LT086 } & $(\mathrm{CTT}) 10$ & AAGACAGGACTTT & GAACGAACCTAACCA & 274 & $\mathrm{~N}$ & 55 \\
\hline & & CCACTGA & AATGA & & & \\
\hline \multirow[t]{2}{*}{ LT096 } & (CT)20 & TGCAACCTAACAA & TGAAAAGCAACCAAG & 272 & $\mathrm{~N}$ & 55 \\
\hline & & GATGTGT & TTACC & & & \\
\hline \multirow[t]{2}{*}{ LT131 } & (AC)22 & GCAGCATCTCCTC & TTGCAGTTGAGCTATT & 240 & $\mathrm{Y}$ & 55 \\
\hline & & ATATTCT & GTTG & & & \\
\hline \multirow[t]{2}{*}{ LT157 } & (TTC)6 & AGTTGCCCTTTAGC & GCCACAGAGTTTTGGA & 222 & $\mathrm{Y}$ & 55 \\
\hline & & TTCTTT & AGTA & & & \\
\hline \multirow[t]{2}{*}{ LTCU19 } & $(\mathrm{AG}) 10$ & GTGGATTGCAAAG & AAAACAAAAGCAAGC & 183 & $\mathrm{~N}$ & 57 \\
\hline & & GCAGAGT & AAGCC & & & \\
\hline \multirow[t]{2}{*}{ LTCU40 } & (ATG)8 & TTGCGTAAATGCA & GAAGCCtaTGCAAGAT & 181 & $\mathrm{Y}$ & 55 \\
\hline & & TCCAAAA & GCAA & & & \\
\hline \multirow[t]{2}{*}{ LTCU51 } & (CT) 18 & ATCACCATCTTCCT & AAACCATTCCAACCAT & 198 & $\mathrm{~N}$ & 55 \\
\hline & & CATCGC & CCAA & & & \\
\hline \multirow[t]{2}{*}{ LTCU53 } & (TG) 14 & CGGATCTTTCTCTT & AAGAAGATTGCAGAG & 223 & $\mathrm{~N}$ & 55 \\
\hline & & TCCATCC & GCAGAA & & & \\
\hline \multirow[t]{2}{*}{ LTCU125 } & (TC) 8 & CGAAAGACATTCC & CCATTACAATCCACAG & 205 & $\mathrm{~N}$ & 55 \\
\hline & & CATCACA & CCAA & & & \\
\hline \multirow[t]{2}{*}{ LTCU139 } & $(\mathrm{TCT}) 10$ & GAATAACCGCTCT & AAGCCAAGTGGCAAA & 164 & $\mathrm{Y}$ & 55 \\
\hline & & TTTGGGA & GAAGA & & & \\
\hline \multirow[t]{2}{*}{ LTCU142 } & $(\mathrm{AAT}) 8$ & TGGTGCATATGGG & TATTCCCCCAGCTTCT & 171 & $\mathrm{Y}$ & 55 \\
\hline & & CTTAGAA & CCTT & & & \\
\hline \multirow[t]{2}{*}{ LTCU143 } & (TG)13 & AAAAATGCTAATC & TATCCAACCGATCACC & 160 & $\mathrm{~N}$ & 55 \\
\hline & & CAATAACTTTCG & CATT & & & \\
\hline \multirow[t]{2}{*}{ LTCU145 } & (GA)18 & TTGAAGTCCAGAT & GCCTAGGGaGATGtTTT & 157 & $\mathrm{~N}$ & 55 \\
\hline & & TGATTGATTG & TGG & & & \\
\hline \multirow[t]{2}{*}{ LTCU150 } & (TC) 10 & TCTTCAAACCAAG & GCACTACATCCСТTTTc & 167 & $\mathrm{~N}$ & 55 \\
\hline & & GCTGTTG & CCA & & & \\
\hline \multirow[t]{2}{*}{ LTCU151 } & (TC) 11 & TGAGGTGACTTTG & GACCCgaGCTGTAAAA & 189 & $\mathrm{~N}$ & 55 \\
\hline & & GCTTTTG & TGGA & & & \\
\hline \multirow[t]{2}{*}{ LTCU152 } & (CA)17 & CATCCAAATGCAG & ATTCCCACTCGGTTGA & 177 & $\mathrm{~N}$ & 55 \\
\hline & & CAGAAAT & ACAC & & & \\
\hline \multirow[t]{2}{*}{ LTCU154 } & $(\mathrm{CT}) 10$ & GATGAAGGAGAAT & CCAGCCAAGAAAGAA & 156 & $\mathrm{~N}$ & 55 \\
\hline & & TCTATATTTTCTGA & AATGG & & & \\
\hline
\end{tabular}

${ }^{a} Y: Y e s ; N: N o$. 


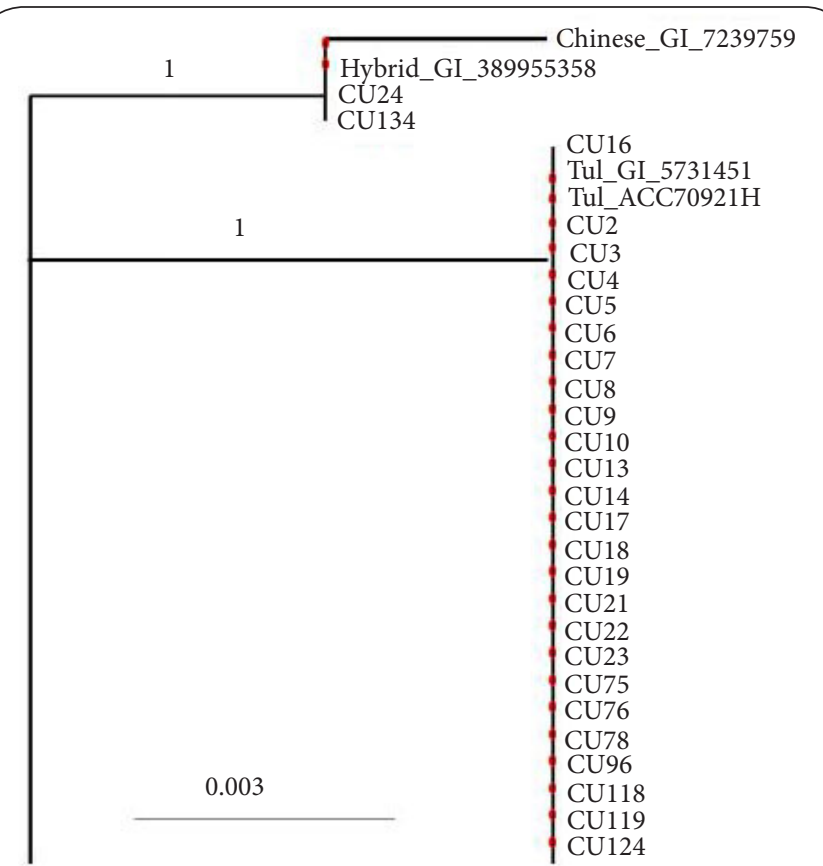

Figure 1. Sequence comparison of maturase $\mathrm{K}$ gene. The sequences were aligned with MUSCLE the phylogenetic tree was built with maximum likelihood (PhyML). The maturase $\mathrm{K}$ gene sequence of L. tulipifera (GI: 5731451), L. chinense (GI: 7239759), and a hybrid (GI: 389955358 ) available in GenBank were included in the analysis. The complete illustration of the tree is included in the Supplementary figure S1.

findings of $72.4 \%$ success rate by [42] and $82.1 \%$ by [43]. This is expected because EST-SSRs have generally demonstrated a high frequency of cross-species transferability despite less polymorphism compared to genomic SSRs $[\mathbf{9}, \mathbf{1 2}, \mathbf{4 4}]$. Among the 194 L. tulipifera trees included in the study, the number of alleles per locus ranged from 3 to 26 (mean=13.0) (Table 2). The observed and expected heterozygosities ( $\mathrm{Ho}$ and $\mathrm{He}$ ) ranged from 0.17 to 0.89 and from 0.19 to 0.93 , with averages of 0.62 and 0.74 , respectively. The polymorphic information content (PIC) ranged from 0.17 to 0.92 , with an average of 0.71 . Overall, 14 of the 15 markers had a PIC $\geq 0.5$.

Many genomic resources, such as expressed sequence tag (EST) databases $[15,22,23]$ and genomic DNA libraries [24], have been developed for L. tulipifera. Through these resources, several thousand putative SSR markers have been identified by in silico mining. However, only 345 L. tulipifera SSR markers having been tested for polymorphism by polyacrylamide denaturing gels $[42,43]$. Compared to other species, Liriodendron has lacked development of polymorphic and informative SSR markers.

As a result, no genetic linkage maps of Liriodendron have been reported. This is in contrast with the species'ecological and economic value and phylogenetic position as a basal angiosperm.
Table 2. Statistics of the $\mathbf{1 5}$ markers analyzed by cervus.

\begin{tabular}{llllll}
\hline Locus & K & N & HO & HE & PIC \\
\hline LT002 & 6 & 174 & 0.72 & 0.69 & 0.65 \\
LT015 & 6 & 172 & 0.55 & 0.60 & 0.54 \\
LT021 & 3 & 173 & 0.17 & 0.19 & 0.18 \\
LT086 & 7 & 170 & 0.36 & 0.53 & 0.50 \\
LT096 & 15 & 165 & 0.65 & 0.76 & 0.73 \\
LTCU19 & 12 & 174 & 0.60 & 0.71 & 0.69 \\
LTCU51 & 18 & 172 & 0.74 & 0.87 & 0.85 \\
LTCU53 & 13 & 167 & 0.63 & 0.84 & 0.82 \\
LTCU125 & 18 & 164 & 0.88 & 0.89 & 0.88 \\
LTCU143 & 14 & 164 & 0.74 & 0.80 & 0.76 \\
LTCU145 & 11 & 172 & 0.84 & 0.86 & 0.84 \\
LTCU150 & 15 & 172 & 0.51 & 0.74 & 0.72 \\
LTCU151 & 11 & 158 & 0.51 & 0.76 & 0.73 \\
LTCU152 & 19 & 143 & 0.65 & 0.93 & 0.92 \\
LTCU154 & 26 & 160 & 0.74 & 0.93 & 0.92 \\
Average & 13 & 167 & 0.62 & 0.74 & 0.71 \\
\hline
\end{tabular}

K: number of alleles; N: number of individuals; H0: observed heterozygosity; He: expected heterozygosity; PIC: polymorphic information content.

\section{Genetic composition of the L. tulipifera orchards}

While there were only two loci (LT002 and LT015) significantly deviating from Hardy-Weinberg proportions in the Clemson population, there were 10 deviating loci in the Knoxville population ( $p>0.05$ ) (Supplementary Table S1 and S2). This may be due to insufficient sample size from the Knoxville population. As shown in Tables 3 and $\mathbf{4}$, the Clemson orchard had higher values for observed number of alleles (15.3 vs 7.4), effective number of alleles ( 5.9 vs 4.0 ), observed $(\mathrm{Ho}$, 0.64 vs 0.58 ) and expected heterozygosity ( $\mathrm{He}, 0.74$ vs 0.70 ), Nei's expected heterozygosity ( 0.74 vs 0.58 ), and Shannon's Information index (1.85 vs 1.51) than the Knoxville orchard. However, the differences were not statistically significant ( $p=0.05$, $\mathrm{t}$-Test) except for observed number of alleles. The different number of trees from the orchards included in the study, 163 from the Clemson vs 31 from the Knoxville, may be a contributing factor.

This is the first report of genetic composition of Liriodendron cultivated populations in North America and has provided the basic data of genetic diversity and allele richness among selections of this unique native species. [43] examined 27 trees from a cultivated population of $L$. tulipifera in the Jurong, Jiangsu Province of China with 39 polymorphic EST-SSR loci through electrophoreses in $6 \%$ polyacrylamide denaturing gels and visualization with silver nitrate staining. It was found that the number of alleles per locus ranged from three to 18 and the average $\mathrm{Ho}$ and $\mathrm{He}$ were 0.68 and 0.78 , respectively. Compared to this cultivated population in China, the two 
Table 3. Genetic variation at 15 EST-SSR loci characterized in the clemson orchard.

\begin{tabular}{llllllllll}
\hline \multicolumn{1}{c}{ Clemson orchard (163 trees) } \\
\hline Locus & Sample size & Na & Ne & Obs_Hom & Obs_Het & Exp_Hom & Exp_Het & Nei's & I \\
\hline LT002 & 326 & 6.00 & 3.16 & 0.28 & 0.72 & 0.31 & 0.69 & 0.68 & 1.35 \\
LT015 & 324 & 8.00 & 2.30 & 0.46 & 0.54 & 0.43 & 0.57 & 0.57 & 1.11 \\
LT021 & 324 & 6.00 & 1.99 & 0.54 & 0.46 & 0.50 & 0.50 & 0.50 & 1.01 \\
LT086 & 318 & 9.00 & 1.84 & 0.69 & 0.31 & 0.54 & 0.46 & 0.46 & 1.00 \\
LT096 & 308 & 18.00 & 3.75 & 0.38 & 0.62 & 0.26 & 0.74 & 0.73 & 1.80 \\
LTCU19 & 326 & 15.00 & 3.20 & 0.40 & 0.60 & 0.31 & 0.69 & 0.69 & 1.71 \\
LTCU51 & 324 & 18.00 & 7.74 & 0.26 & 0.74 & 0.13 & 0.87 & 0.87 & 2.26 \\
LTCU53 & 310 & 13.00 & 4.84 & 0.30 & 0.70 & 0.20 & 0.80 & 0.79 & 1.89 \\
LTCU125 & 308 & 26.00 & 11.46 & 0.05 & 0.95 & 0.08 & 0.92 & 0.91 & 2.75 \\
LTCU143 & 306 & 14.00 & 4.84 & 0.23 & 0.77 & 0.20 & 0.80 & 0.79 & 1.81 \\
LTUCU145 & 324 & 12.00 & 7.49 & 0.17 & 0.83 & 0.13 & 0.87 & 0.87 & 2.18 \\
LTUCU150 & 322 & 14.00 & 2.90 & 0.42 & 0.58 & 0.34 & 0.66 & 0.66 & 1.61 \\
LTUCU151 & 294 & 9.00 & 2.99 & 0.54 & 0.46 & 0.33 & 0.67 & 0.67 & 1.38 \\
LTUCU152 & 258 & 25.00 & 15.89 & 0.33 & 0.67 & 0.06 & 0.94 & 0.94 & 2.91 \\
LTUCU154 & 302 & 37.00 & 14.49 & 0.28 & 0.72 & 0.07 & 0.93 & 0.93 & 3.03 \\
Mean & 312 & 15.33 & 5.93 & 0.36 & 0.64 & 0.26 & 0.74 & 0.74 & 1.85 \\
St. Dev. & -- & 8.53 & 4.59 & 0.16 & 0.16 & 0.15 & 0.15 & 0.15 & 0.66 \\
\hline
\end{tabular}

Na: Observed number of alleles. Ne: Effective number of alleles (Kimura and Crow 1964). Obs_Hom/Obs_ Het: Observed homozygosity/heterozygosity. Ext_Het/Exp_Het: expected homozygosity/heterozygosity (Levene 1949). Nei's (1973) expected heterozygosity. I=Shannon's Information index (Lewontin 1972). St. Dev.: Standard deviation.

Table 4. Genetic variation at 15 EST-SSR loci characterized in the knoxville orchard.

\begin{tabular}{llllllllll}
\hline \multicolumn{10}{c}{ Knoxville orchard (31 trees) } \\
\hline Locus & Sample size & $\mathbf{N a}$ & Ne & Obs_Hom & Obs_Het & Exp_Hom & Exp_Het & Nei's & I \\
LT002 & 62 & 5 & 3.65 & 0.32 & 0.68 & 0.26 & 0.74 & 0.73 & 1.43 \\
LT015 & 60 & 5 & 3.38 & 0.43 & 0.57 & 0.28 & 0.72 & 0.7 & 1.36 \\
LT021 & 62 & 2 & 1.17 & 0.84 & 0.16 & 0.85 & 0.15 & 0.15 & 0.28 \\
LT086 & 62 & 6 & 2.81 & 0.35 & 0.65 & 0.35 & 0.65 & 0.64 & 1.22 \\
LT096 & 62 & 10 & 4.75 & 0.32 & 0.68 & 0.2 & 0.8 & 0.79 & 1.85 \\
LTCU19 & 62 & 9 & 3.59 & 0.52 & 0.48 & 0.27 & 0.73 & 0.72 & 1.68 \\
LTCU51 & 60 & 12 & 5.84 & 0.27 & 0.73 & 0.16 & 0.84 & 0.83 & 2 \\
LTCU53 & 62 & 6 & 2.77 & 0.74 & 0.26 & 0.35 & 0.65 & 0.64 & 1.32 \\
LTCU125 & 60 & 15 & 6.14 & 0.3 & 0.7 & 0.15 & 0.85 & 0.84 & 2.17 \\
LTCU143 & 60 & 8 & 5.26 & 0.33 & 0.67 & 0.18 & 0.82 & 0.81 & 1.8 \\
LTUCU145 & 60 & 8 & 4.64 & 0.1 & 0.9 & 0.2 & 0.8 & 0.78 & 1.71 \\
LTUCU150 & 62 & 5 & 3.29 & 0.68 & 0.32 & 0.29 & 0.71 & 0.7 & 1.33 \\
LTUCU151 & 56 & 3 & 2.26 & 0.39 & 0.61 & 0.43 & 0.57 & 0.56 & 0.89 \\
LTUCU152 & 62 & 9 & 5.88 & 0.42 & 0.58 & 0.16 & 0.84 & 0.83 & 1.93 \\
LTUCU154 & 58 & 8 & 3.83 & 0.24 & 0.76 & 0.25 & 0.75 & 0.74 & 1.62 \\
Mean & 61 & 7.4 & 3.95 & 0.42 & 0.58 & 0.29 & 0.70 & 0.58 & 1.51 \\
St. Dev. & -- & 3.4 & 1.44 & 0.20 & 0.20 & 0.17 & 0.17 & 0.16 & 0.46 \\
\hline
\end{tabular}

Na: Observed number of alleles. Ne: Effective number of alleles (Kimura and Crow 1964). Obs_ Hom/Obs_Het: Observed homozygosity/heterozygosity. Ext_Het/Exp_Het: expected homozygosity/ heterozygosity (Levene 1949). Nei's (1973) expected heterozygosity. I=Shannon's Information index (Lewontin 1972). St. Dev.: Standard deviation. 
US orchards had slightly lower values of average $\mathrm{Ho}$ and $\mathrm{He}$, with $0.64(\mathrm{Ho})$ and $0.74(\mathrm{He})$ in the Clemson orchard and $0.58(\mathrm{Ho})$ and $0.70(\mathrm{He})$ in the Knoxville orchard. These values are comparable to those reported in a $L$. chinense cultivated population in China, which had a $\mathrm{Ho}$ and $\mathrm{He}$ of 0.48 and 0.74 [43]. Other forest tree species have similar heterozygosities as well, for example, a Pinus merkusii parental and seedling populations had a He of 0.55 and 0.49 , respectively $[10,30]$. Reported $0.48(\mathrm{Ho})$ and $0.63(\mathrm{He})$ in a white spruce plantation and $0.49 \mathrm{Ho}$ ) and $0.63(\mathrm{He})$ in a white spruce improvement selection population. It is noteworthy that genetic diversity of natural L. tulipifera populations has been reported [e.g., 18,32] . However these studies utilized either allozymes or amplified fragment length polymorphism (AFLP) markers, which usually have lower information content than SSR markers. None of the reported expected heterozygosities from these studies exceeded 0.29 . Overall, substantial genetic diversity is captured in the Clemson and Knoxville seed orchards.

\section{Conclusion}

The data obtained in this study will be useful in future applications such as prediction of genetic gain and gene diversity in the seed orchards. Nei's genetic distance between the two orchards was 0.39 , which was the lowest among all comparisons (Table 5). The L. chinense and L. tulipifera trees from the National Arboretum exhibited the largest genetic distance (1.17). The two orchards and the L. tulipifera sample from the US National Arboretum grouped together in the UPGMA dendrogram. The genetic distance of the hybrids in the Clemson orchard was closest to the Clemson orchard (0.50), followed by the Knoxville orchard $(0.80)$ and $L$. chinense from the National Arboretum (0.88), and then by the L. tulipifera from the National Arboretum (1.17) (Figure 2). With a widespread range of distribution, L. tulipifera has adapted to many different ecological conditions and is one of the species becoming increasingly dominant in forests due to its quick respond to increases in light to the forest floor and rapid initial growth rate [8]. Its increasingly important roles in forestry and wood products is making studying Liriodendron of great interest. Our study provides a first look at the genetic diversity and allele richness among selections of this unique native species,

Table 5. Nei's (1978) unbiased identity (above diagonal) and distance (below diagonal).

\begin{tabular}{llllll}
\hline Pop ID & Clemson & Knoxville & $\begin{array}{l}\text { NA } L . \\
\text { chinense }\end{array}$ & $\begin{array}{l}\text { Hybrids in } \\
\text { Clemson }\end{array}$ & $\begin{array}{l}\text { NA } L . \\
\text { chinense }\end{array}$ \\
\hline Clemson & -- & 0.6792 & 0.6234 & 0.6051 & 0.4051 \\
Knoxville & 0.3869 & -- & 0.4648 & 0.4484 & 0.3495 \\
NA $L$. & 0.4725 & 0.7662 & -- & 0.3608 & 0.3097 \\
$\begin{array}{l}\text { tulipifera } \\
\text { Hybrids in }\end{array}$ & 0.5025 & 0.8021 & 1.0195 & -- & 0.4138 \\
clemson & & & & & \\
$\begin{array}{l}\text { NA } L . \\
\text { chinense }\end{array}$ & 0.9037 & 1.0513 & 1.1721 & 0.8823 & -- \\
\hline
\end{tabular}

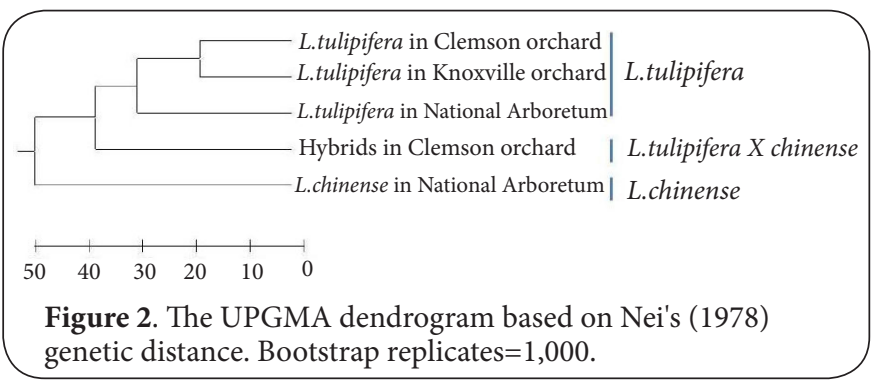

and provides a foundation for further genetic and breeding exploration. The polymorphic markers developed in this study will serve as a resource enabling the future study of population dynamics and adaptive variation in Liriodendron.

\section{Additional files}

\section{Supplementary Table S1 \\ Supplementary Table S2 \\ Supplementary figure $\mathbf{S 1}$ \\ Supplementary figure S2 \\ Supplementary figure S3}

Competing interests

The authors declare that they have no competing interests.

\section{Authors' contributions}

\begin{tabular}{|l|c|c|c|c|c|c|c|}
\hline Authors' contributions & XZ & AC & ZT & MS & SES & JEC & HL \\
\hline Research concept and design & -- & -- & -- & -- & -- & $\checkmark$ & $\checkmark$ \\
\hline Collection and/or assembly of data & $\checkmark$ & $\checkmark$ & $\checkmark$ & $\checkmark$ & $\checkmark$ & -- & -- \\
\hline Data analysis and interpretation & $\checkmark$ & -- & -- & -- & -- & -- & $\checkmark$ \\
\hline Writing the article & $\checkmark$ & -- & -- & -- & -- & -- & $\checkmark$ \\
\hline Critical revision of the article & -- & -- & -- & $\checkmark$ & $\checkmark$ & -- & $\checkmark$ \\
\hline Final approval of article & $\checkmark$ & $\checkmark$ & $\checkmark$ & $\checkmark$ & $\checkmark$ & $\checkmark$ & $\checkmark$ \\
\hline Statistical analysis & $\checkmark$ & -- & -- & -- & -- & -- & $\checkmark$ \\
\hline
\end{tabular}

\section{Acknowledgement}

The authors thank Nick Wheeler for his guidance and thorough review of the manuscript. The funding for the study came from the NSF Plant Genome Research program (NSF 1025974) and National Institute of Food and Agriculture, USDA SC-1700449 with a Clemson University Experiment Station technical contribution number of 6215).

\section{Publication history}

Editor: Shouan Zhang, University of Florida, USA. Received: 21-Jan-2015 Revised: 24-Feb-2015

Accepted: 17-Mar-2015 Published: 27-Mar-2015

\section{References}

1. Altschul SF, Madden TL, Schaffer AA, Zhang J, Zhang Z, Miller W and Lipman DJ. Gapped BLAST and PSI-BLAST: a new generation of protein database search programs. Nucleic Acids Res. 1997; 25:3389-402. | Article | PubMed Abstract | PubMed Full Text

2. Bae $K$ and Byun J. Screening of leaves of higher plants for antibacterial action. Kor J Pharmacogn. 1987; 8:1.

3. Beck DE. Liriodendron tulipifera L. Yellow-poplar. In Silvics of North 
America. Harwoods. Edited by R.M. Burns and B.H. Honkala. US Dep Agric Agric Handb 654. 1990; 2:406-416. | Article

4. Beckage $B$ and Clark JS. Seedling survival and growth of three forest tree 328 species: The role of spatial heterogeneity. Ecology. 2003; 84:18491861. I Pdf

5. Bonner FT and Russell TE. Liriodendron tulipifera L. Yellow-poplar. In Schopmeyer, CS (Tech. Coord.). Seeds of woody plants of the United States. USDA For Serv Agric Handb. 1974; 450:508-511.

6. Cech F, Brown J and Weingartner D. Wind damage to a yellow-poplar seed orchard. Tree Planters' Notes. 1976; 27:3-4.

7. Dereeper A, Guignon V, Blanc G, Audic S, Buffet S, Chevenet F, Dufayard JF, Guindon S, Lefort V, Lescot M, Claverie JM and Gascuel O. Phylogeny. fr: robust phylogenetic analysis for the non-specialist. Nucleic Acids Res. 2008; 36:W465-9. | Article | PubMed Abstract | PubMed Full Text

8. Dyer JM. Using witness trees to assess forest change in southeastern Ohio. Can J Bot. 2001; 31:1708-1718. | Article

9. Ellis JR and Burke JM. EST-SSRs as a resource for population genetic analyses. Heredity (Edinb). 2007; 99:125-32. | Article I PubMed

10. Fageria MS and Rajora OP. Effects of silvicultural practices on genetic diversity and population structure of white spruce in Saskatchewan Tree Gene Genome. 2014; 10:287-296. I Article

11. Forest Service. Forest Inventory and Analysis National Program, The United State Department of Agriculture. FIADB 5.1.6 ed. 2014. I Website

12. Han Y, Chagne D, Gasic K, Rikkerink EH, Beever JE, Gardiner SE and Korban SS. BAC-end sequence-based SNPs and Bin mapping for rapid integration of physical and genetic maps in apple. Genomics. 2009; 93:282-8. | Article | PubMed

13. Hernandez R, Davalos JF, Sonti SS, Kim Y and Moody RC. Strength and stiffness of reinforced yellow-poplar glued laminated beams. Res. Pap. FPL-RP-U.S. Department of Agriculture, Forest Service, Forest Products Laboratory, Madison, WI. 1997. I Pdf

14. Huang MR and Chen DM. An isozyme analysis of tulip-tree hybrids (Liriodendron Chinese X L. tulipifera). J Nanjing For Univ. 1979; 1:156158. | Article

15. Jin H, Do J, Moon D, Noh EW, Kim W and Kwon M. EST analysis of functional genes associated with cell wall biosynthesis and modification in the secondary xylem of the yellow poplar (Liriodendron tulipifera) stem during early stage of tension wood formation. Planta. 2011; 234:959-77. | Article | PubMed

16. Kimura $M$ and Crow JF. The measurement of effective population number. Evolution. 1964; 17:279-288. I Article

17. Kobayashi N, Horikishi T, Katsuyama H, Handa T and Takayanagi K. A simple and efficient DNA extraction method for plants, especially woody plants. Plant Tissue Culture Biotechnol. 1998; 4:76-80. | $\underline{\text { Article }}$

18. Kovach KE. Assessment of genetic variation of Acer rubrum L. and Liriodendron tulipifera L. populations in unmanaged forests of the Southeast United States. 2009. I Article

19. Levene $\mathrm{H}$. On a matching problem arising in genetics. Ann Math Stat. 1949; 20:91-94. | Article

20. Lewontin RC. The apportionment of human diversity. Evol Biol. 1972; 6:381-398. | $\underline{\mathrm{Pdf}}$

21. Li Z and Wang Z. RAPD markers used for the hybrid identification and parents choice in Liriodendron. Sci Silv Sinic. 2002; 38:169-174. | Article

22. Liang H, Ayyampalayam S, Wickett N, Barakat A, Xu Y, Landherr L, Ralph P, Xu T, Schlarbaum SE, Leebens-Mack JH and dePamphilis CW. Generation of a large-scale genomic resource for functional and comparative genomics in Liriodendron. Tree Gen Genom. 2011; 7:941-954. | Article

23. Liang $\mathrm{H}$, Carlson JE, Leebens-Mack JH, Wall PK, Mueller LA, Buzgo M, Landherr LL, Hu Y, DiLoreto DS, Ilut DC, Field D, Tanksley SD, Ma H and dePamphilis CW. A 378 n EST Database for Liriodendron tulipifera L. floral buds: the first EST resource for functional and comparative genomics in Liriodendron. Tree Genet Genomes. 2008; 4:419-433. | Article

24. Liang H, Feng E, Tomkins J, Arumuganathan K, Zhao S, Luo M, Kudrna D, Wing R, Banks J, dePamphilis C, Mandoli D, Schlarbaum S and Carlson JE. Development of a BAC library resource for yellow poplar (Liriodendron tulipifera) and the identification of genomic regions associated with flower development and lignin biosynthesis. Tree Genet Genomes. 2007; 3:215-225. I Article

25. Marshall TC, Slate J, Kruuk LE and Pemberton JM. Statistical confidence for likelihood-based paternity inference in natural populations. Mol Ecol. 1998; 7:639-55. | Article | PubMed

26. Merkle SA, Hoey MT, Watson-Pauley BA and Schlarbaum SE. Propagation of Liriodendron hybrids via somatic embryogenesis. Plant Cell Tissue Organ Cult. 1993; 34:191-198. I Article

27. Moon MK, Oh HM, Kwon BM, Baek NI, Kim SH, Kim JS and Kim DK. Farnesyl protein transferase and tumor cell growth inhibitory activities of lipiferolide isolated from Liriodendron tulipifera. Arch Pharm Res. 2007; 30:299-302. | Article | PubMed

28. Nei M. Analysis of gene diversity in subdivided populations. Proc Natl Acad Sci U S A. 1973; 70:3321-3. | PubMed Abstract | PubMed Full Text

29. Nei M. Estimation of average heterozygosity and genetic distance from a small number of individuals. Genetics. 1978; 89:583-90. | Article | PubMed Abstract | PubMed Full Text

30. Nurtjahjaningsih ILG, Saito Y, Tsuda Y and Ide Y. Genetic diversity of parental and offspring populations in a Pinus merkusii seedling seed orchard detected by microsatellite markers. Bulletin of the Tokyo University Forest, the Tokyo University Forests. 2007; 118:1-14. I Pdf

31. Parks CR, Miller NG, Wendel JF and Mc-Dougal KM. Genetic divergence within the genus Liriodendron (Magnoliaceae). Ann Miss Bot Gard. 1983; 70:658-666. | Article

32. Parks CR and Wendel JF. Molecular divergence between Asian and North American species of Liriodendron (Magnoliaceae) with implications for interpretation of fossil floras. Am J Bot. 1990; 77:1243-1256. | Article

33. Raymond $M$ and Rousset F. GENEPOP (version 1.2): population genetics software for exact tests and ecumenisms. J Heredity. 1995; 86:248-249. | Article

34. Santamour FS. Interspecific hybrids in Liriodendron and their chemical verification. Fort Sci. 1972; 18:233-236. I Article

35. Sewell MM, Parks CR and Chase MW. Intraspecific chloroplast DNA variation and biogeography of North American Liriodendron L. (Magnoliaceae). Evolution. 1996; 50:1147-1154. | Article

36. Thor E. Tree Breeding at the University of Tennessee, 1959-1976. Univ Tenn Ag Exp Stn Bull, 1976; 48. I Article

37. Turmel $M$, Otis $C$ and Lemieux $C$. The chloroplast genome sequence of Chara vulgaris sheds new light into the closest green algal relatives of land plants. Mol Biol Evol. 2006; 23:1324-38. | Article | PubMed

38. van Oosterhout C, Hutchinson WF, Wills DPM and Shipley P. MICROCHECKER: software for identifying and correcting genotyping errors in microsatellite data. Mol Ecol Notes. 2004; 4:535-538. | Article

39. Wang Z. Utilization and species hybridization in Liriodendron. Chinese Forestry Press, Beijing. 2005.

40. Wicke $S$ and Quandt D. Universal primers for the amplification of the plastid trnK/matK region in land plants. Anales Jard Bot Madrid. 2009; 66:285-288. I Article

41. Williams RS and Feist WC. Durability of yellow-poplar and sweetgum and service life of finishes after long-term exposure. Forest Products J. 2004; 54:96-101. I Article

42. Xu M, Sun Y and Li H. EST-SSRs development and paternity analysis for Liriodendron spp. New Forests. 2010; 40:361-382. I Article

43. Yang $\mathrm{AH}$, Zhang JJ, Tian $\mathrm{H}$ and Yao XH. Characterization of 39 novel ESTSSR markers for Liriodendron tulipifera and cross-species amplification in L. chinense (Magnoliaceae). Am J Bot. 2012; 99:e460-4. | Article | PubMed

44. Yu JK, La Rota M, Kantety RV and Sorrells ME. EST derived SSR markers for comparative mapping in wheat and rice. Mol Genet Genomics. 2004; 271:742-51. | Article | PubMed

45. Zane $L$, Bargelloni $L$ and Patarnello T. Strategies for microsatellite isolation: a review. Mol Ecol. 2002; 11:1-16. I Article I PubMed

46. Zhang LJ, Oswald BP and Green TH. Relationships between overstory species and community classification of the Sipsey Wilderness, Ala- 
Zhang et al. Journal of Plant Science \& Molecular Breeding 2015, http://www.hoajonline.com/journals/pdf/2050-2389-4-1.pdf

bama. For Ecol Manage. 1999; 114:377-383. | $\underline{\text { Article }}$

47. Zhang $\mathrm{H}$, Li H, Xu M and Feng Y. Identification of Liriodendron tulipifera, Liriodendron chinense and hybrid Liriodendron using species-specific SSR markers. Sci Silv Sinic. 2012; 46:36-39.

\section{Citation:}

Zhang X, Carlson A, Tian Z, Staton M, Schlarbaum SE, Carlson JE and Liang H. Genetic characterization of Liriodendron seed orchards with EST-SSR markers. J Plant Sci Mol Breed. 2015; 4:1.

http://dx.doi.org/10.7243/2050-2389-4-1 